\title{
Revision of three species of Terebellides (Polychaeta: \\ Trichobranchidae) described by C. Hessle in 1917 from the Southern Ocean
}

\author{
Julio Parapar $^{\mathrm{a}} \&$ Juan Moreira ${ }^{\mathrm{b}}$ \\ a Departamento de Bioloxía Animal, Bioloxía Vexetal e Ecoloxía, Facultade de Ciencias, \\ Universidade da Coruña, A Coruña, Spain; \\ b Estación de Bioloxía Mariña da Graña, Universidade de Santiago de Compostela, Ferrol, \\ Spain
}

Journal of Natural History, Volume 42, 2008 - Issue 17-18

Received 02 Oct 2007, Accepted 31 Jan 2008, Published online: 02 Dec 2010

To cite this article:

Julio Parapar \& Juan Moreira (2008) Revision of three species of Terebellides (Polychaeta: Trichobranchidae) described by C. Hessle in 1917 from the Southern Ocean, Journal of Natural History, 42:17-18, 1261-1275, DOI: 10.1080/00222930801989997

This is an Accepted Manuscript of an article publishing by Taylor \& Francis in Journal of Natural History on 2008, available online: http://www.tandfonline.com/10.1080/00222930801989997

\begin{abstract}
A revision of the taxonomic status of Terebellides antarcticus Hessle, 1917, Terebellides longicaudatus Hessle, 1917 and Terebellides minutus Hessle, 1917 was undertaken through the examination of the type material. Thus, T. longicaudatus is regarded as a valid species and redescribed and $T$. antarcticus and T. minutus are considered as junior synonyms of Terebellides kerguelensis McIntosh, 1818. Terebellides longicaudatus is characterized by the presence of large lateral lobes on chaetigers 1 to 5,1 and 2 being the largest, first thoracic acicular neurochaetae gently bent, wide thoracic neuropodia fascicles with numerous uncini and the first notopodium greatly reduced. Comments on several body characters related to branchial and chaetal structure are also provided.
\end{abstract}

\section{Keywords:}

Annelida; Terebellides longicaudatus; Terebellides antarcticus; Terebellides minutus; Antarctica

\section{Introduction}

The Swedish South Polar Expedition (SSPE) was conducted from 1901 to 1903 in Tierra del Fuego (southern South America), Graham and Palmer coast (Antarctic peninsula) and Falkland Islands, South 
Georgia Island and Shag rocks (Scotia Arc). A number of polychaete families from this cruise were studied by different authors: Maldanidae by Arwidsson (1911), Phyllodocidae and Polynoidae by Bergström $(1914,1916)$, Ampharetidae and Terebellidae by Hessle (1917), Spionidae by Söderström (1920), Sabellidae and Serpulidae by Johansson $(1922,1927)$ and Hesionidae by Hessle (1925). Later, Hartman (1953) listed all the non-pelagic polychaetes collected during the expedition summarizing those previous studies and including additional records. Pelagic species were studied by Støp-Bowitz (1951).

In his worldwide revision of Terebelliform polychaetes, Hessle (1917) revised the material collected during the SSPE describing three new species of Terebellides: Terebellides antarcticus Hessle, 1917. from shallow waters off Graham's Land, and Terebellides minutus Hessle, 1917 and Terebellides longicaudatus Hessle, 1917 from South Georgia Island. The author presented very brief descriptions of the species and differentiated $T$. minutus and $T$. antarcticus from T. stroemii Sars, 1835 and T. longicaudatus according to the shape of thoracic and abdominal uncini. Monro (1930) again reported on T. minutus and T. longicaudatus from South Georgia Island, suggesting that $T$. antarcticus and $T$. minutus could be the same species on the basis that $T$. minutus was a stage in the development of T. antarcticus. Anyway, T. antarcticus and T. minutuswould differ from $T$. longicaudatus "by having the 1st notopod fully developed and by the absence of lateral flaps to the anterior segments" (Monro 1930:198). Soon after, Monro (1939), in a study of the polychaetes collected within the framework of the British, Australian and New Zealand Antarctic Expedition (1929-1931), reported on Terebellides stroemii kerguelensis McIntosh, 1885 which was originally described from the Kerguelen Islands. This subspecies was recently established as a valid species by Parapar and Moreira (2008). After examining McIntosh's types, Monro (1939:148) considered that both $T$. antarcticusand $T$. minutus were synonyms of $T$. kerguelensis.

This synonymy was not subsequently followed up by Hartman (1953:52) who considered the three species of Terebellides described by Hessle (1917) valid. Later, in her catalogue of world polychaetes, Hartman (1959:533) reconsidered the synonymies proposed by Monro (1939) which was eventually reflected in her later compilation on Antarctic "sedentary" polychaetes (Hartman 1966:113). In that work, Hartman (1966:111) mentioned the presence of T. kerguelensis and T. longicaudatus in Antarctic waters while no reference to T. antarcticus was provided. Finally, in her study of the Polychaeta of the Weddell Sea (Hartman 1978:202), she recorded both T. longicaudatus and T. kerguelensis and made no further mention of either T. minutus or T. antarcticus.

Other studies on polychaetes collected during a number of Antarctic cruises such as those by Ehlers (1913) on the "Deutsche Südpolar Expedition", Augener (1932) on the Norwegian Antarctic Expeditions 1927-1928, Monro (1936) on the RRS "Discovery", "Discovery II" and "Scoresby" cruise in South Georgia, Levenstein (1964) on Russian expeditions, Hartman (1967) on the USNS "Eltanin" and "Staten Island" cruises as well as other more recent reports from German, Italian, Polish, and Spanish cruises in the Antarctica (e.g. Hartmann-Schröder and Rosenfeldt 1989, 1991; Cantone and Sanfilippo 1992; Sicinski and Janowska 1993; Parapar and San Martin 1997; San Martin et al. 2000; Sicinski 2004) do not provide any reference to T. longicaudatus. In those papers, T. kerguelensis (as T. stroemii kerguelensis) is the only species reported of this genus in those waters.

In the last three decades, much effort has been placed upon a worldwide revision of the Trichobranchidae diversity, mostly after papers by Williams (1984) and Holthe (1986) (e.g. Kritzler 1984; Imajima and Williams 1985; Solis-Weiss et al. 1991; Bremec and Elias 1999; Hutchings and Peart 2000; Garraffoni and Lana 2003; Díaz-Díaz and Liñero-Arana 2003; Garraffoni and Lana 2004; Garraffoni et al. 2005). In his catalogue of world Terebellomorpha, Holthe (1986:116) still 
considered T. longicaudatusas a valid Antarctic and subantarctic species following Monro (1939) and Hartman (1966), and regarded T. antarcticus and $T$. minutus as synonyms of $T$. kerguelensis (Holthe 1986:117). Nevertheless, Garraffoni et al. (2005:14) recently suggest that new examination of type specimens of $T$. antarcticus and $T$. minutus could re-establish these species as valid. Recent references to T. longicaudatus can be found in Hutchings and Peart (2000:245) and Rozbaczylo et al. (2006:85). The latter authors distinguish T. longicaudatus from T. kerguelensis by the smaller development of the first notopodium in the former.

In the present work, type material of Terebellides antarcticus, $T$. minutus and $T$. longicaudatus and specimens of T. longicaudatus examined by Monro (1930) and Hartman (1978) are revised. As a result of this, the synonymy among $T$. antarcticus, $T$. minutus and $T$. kerguelensis is confirmed. Terebellides longicaudatus is considered here a valid species and the holotype is redescribed to complete the original description by taking into account characters currently used in trichobranchid taxonomy. This paper is a new addition to the taxonomic revision of the genus Terebellides in Antarctic waters, which began with the redescription of T. kerguelensis McIntosh, 1885 by Parapar and Moreira (2008).

\section{Materials and methods}

Type material of Terebellides antarcticus, $T$. minutus and $T$. longicaudatus described by Hessle in 1917Hessle, C. 1917. Zur Kenntnis der terebellomorphen Polychaeten.. Zoologiska bidrag frän Uppsala, 5: 39-258. was loaned by the Swedish Museum of Natural History (SMNH, Stockholm). The specimen of T. longicaudatus used for redescription of the species is registered as SMNH 6626 and labelled as "Holotype". Additional material identified as T. longicaudatus by Monro (1930Monro, C. C. A. 1930. Polychaete worms.. Discovery Reports, 2:1-222.) and Hartman (1978Hartman, O. 1978. Biology of Antarctic Seas, 6. Polychaeta from the Weddell Sea quadrant, Antarctica.. Antarctic Research Series, 26: 125-223.) was loaned by the British Museum of Natural History (BMNH, London) and United States National Museum (USNM, Washington), respectively. The specimens are stored in $70 \%$ ethanol. Observations, drawings and measurements were made using an Olympus SZX9 stereomicroscope and an Olympus BX40 compound microscope, both equipped with a drawing tube. Specimens used for scanning electron microscopy (SEM) were dehydrated via a graded ethanol series, critical-point dried using $\mathrm{CO}_{2}$, covered with gold in a BAL-TEC SCD 004 sputter coater at the SAIN (Universidade da Coruña, Spain), and examined and photographed under a LEICA LEOS 435VP SEM at the RIAIDT (Universidade de Santiago de Compostela, Spain).

\section{Systematics}

Family TRICHOBRANCHIDAE Malmgren, 1866

Genus Terebellides Sars, 1835

Terebellides longicaudatus Hessle, 1917.

(Figures 1-4)

Terebellides longicaudatus Hessle 1917:139, plate I, figure 17, Textfigure 30. 

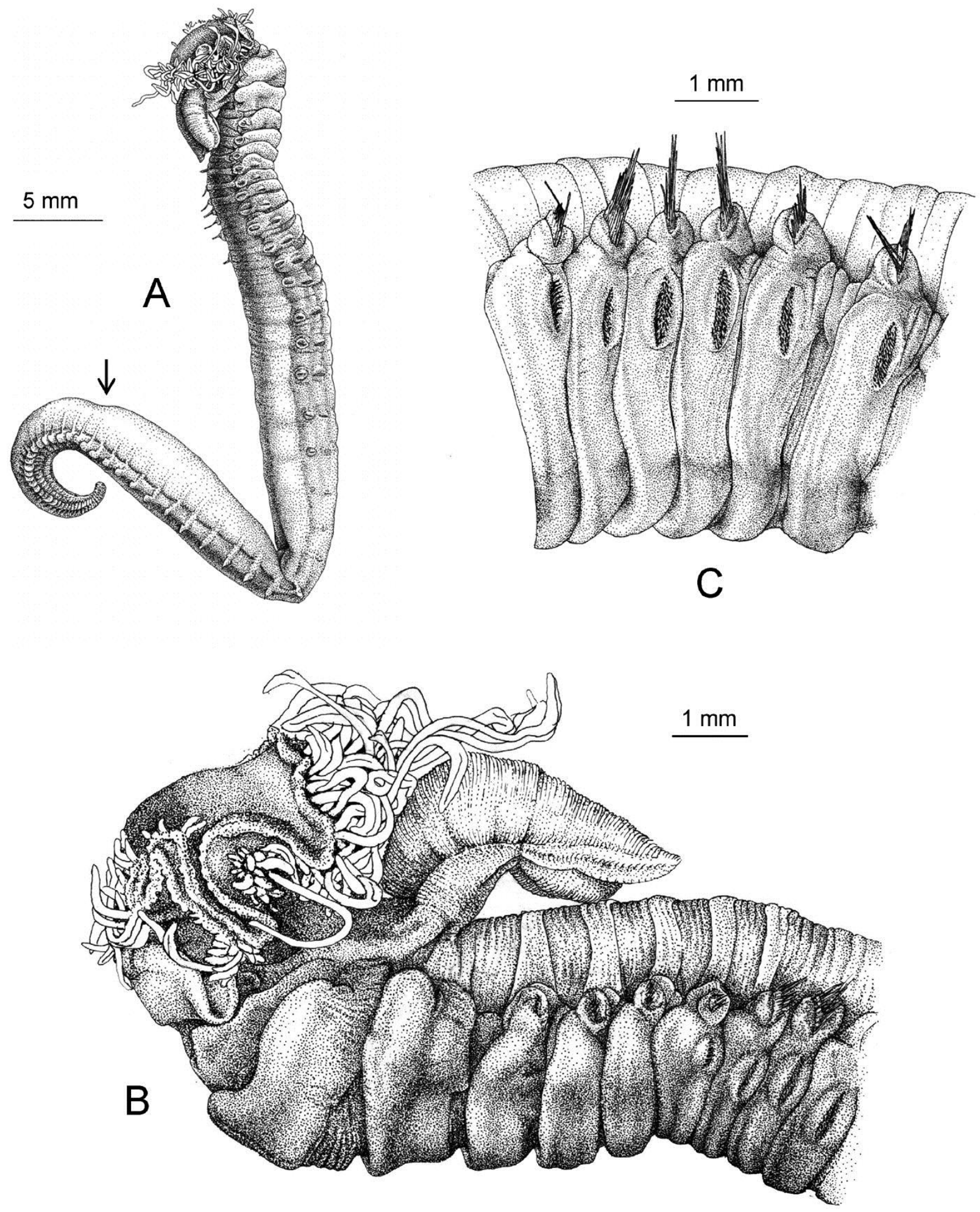

Figure 1 Terebellides longicaudatus Hessle, 1917. (A) Holotype (SMNH 66269), lateral view showing constriction in abdominal chaetiger 17 (arrow); (B) Anterior end, lateral view; (C) Thoracic chaetigers 6-11, latero-ventral view. 


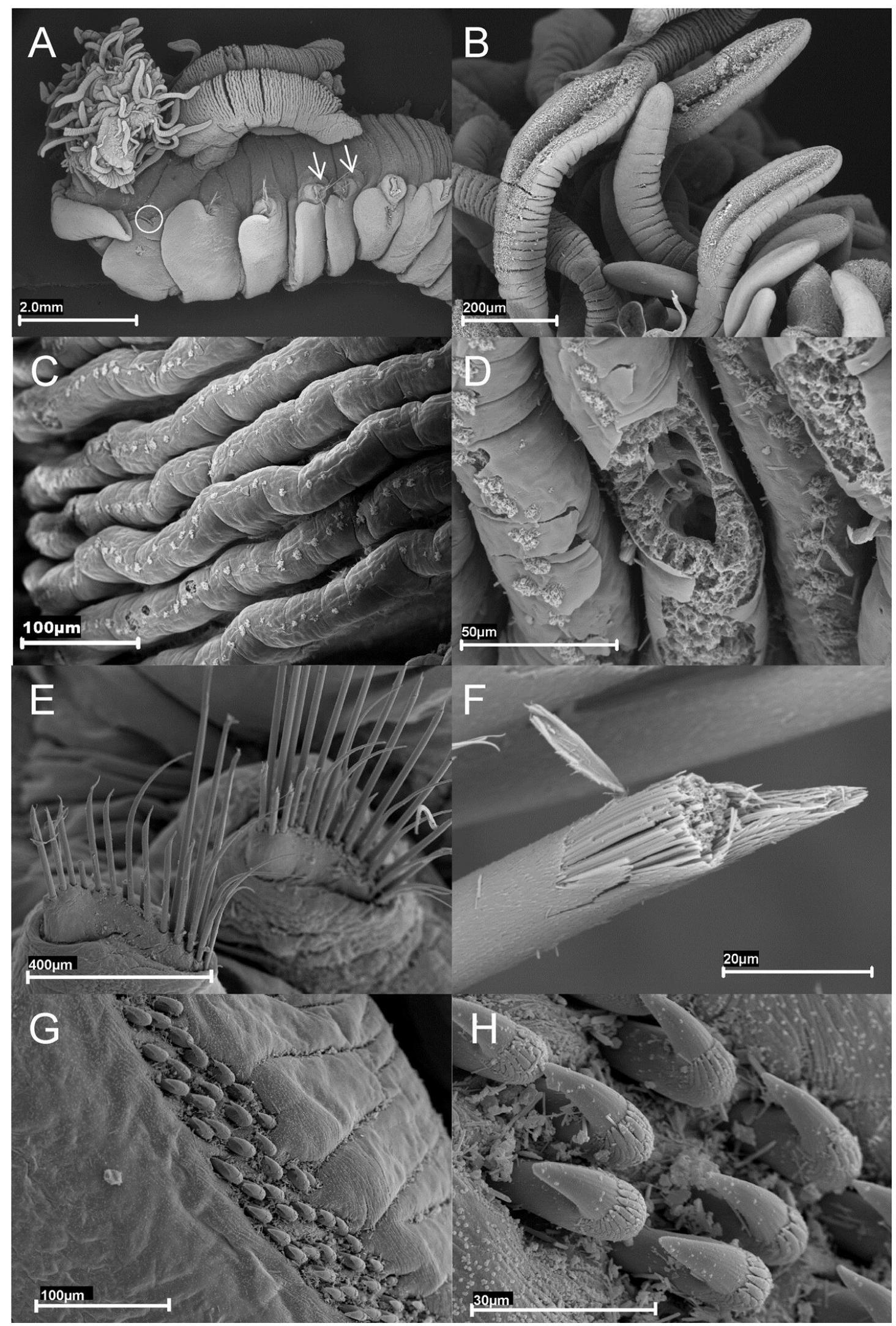

Figure 2 Terebellides longicaudatus Hessle, 1917. SEM micrographs from syntype SMNH 6625. (A) Anterior end, lateral view showing position of first notopodium (encircled) and segmental organs on 4th and 5th chaetigers (arrow); (B) Oral tentacles, distal end, detail; (C) Tufts of cilia of branchial lamellae, dorsal view; (D) Damaged margin of one branchial lamella showing internal structure of marginal efferent blood vessel; (E) Thoracic notochaetae (mostly broken) of chaetigers 10-11; (F) Broken thoracic notochaetae showing internal structure; (G) Thoracic neuropodium of chaetiger 7; $(\mathrm{H})$ Thoracic uncini of chaetiger 7, upper view. 


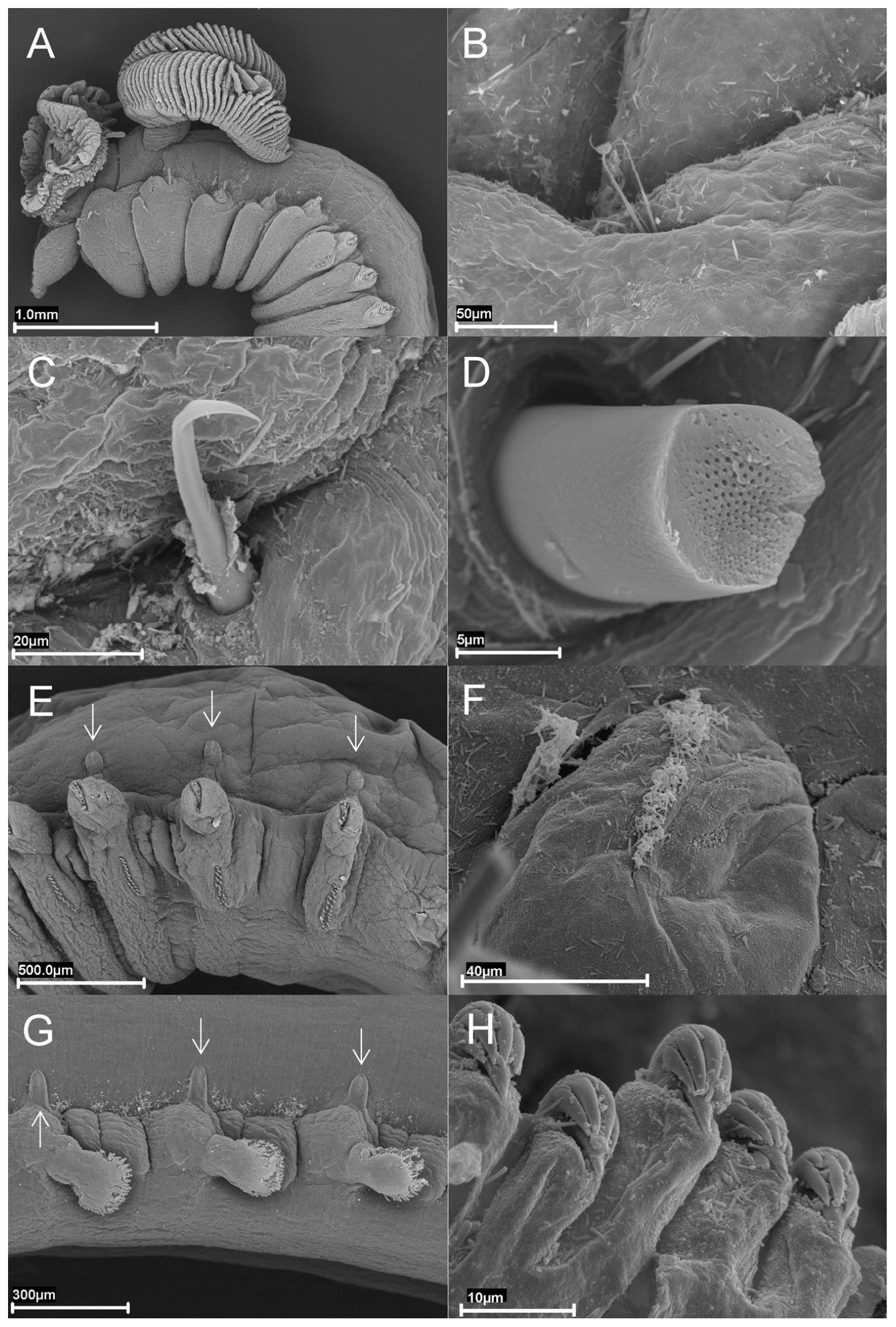

Figure 3 Terebellides longicaudatus Hessle, 1917. SEM micrographs from syntype SMNH 6631. (A) Anterior end, lateral view; (B) Notopodium, first thoracic chaetiger; (C) Geniculate acicular hook, 6th thoracic chaetiger; (D) Geniculate hook, internal structure, detail showing fused inner hollow channels; (E) Thoracic chaetigers 11 to 13, lateral view; (F) Thoracic dorsal papilla; (G) Mid-abdominal chaetigers, lateral view; (H) Abdominal uncini. Arrows show position of dorsal papillae. 


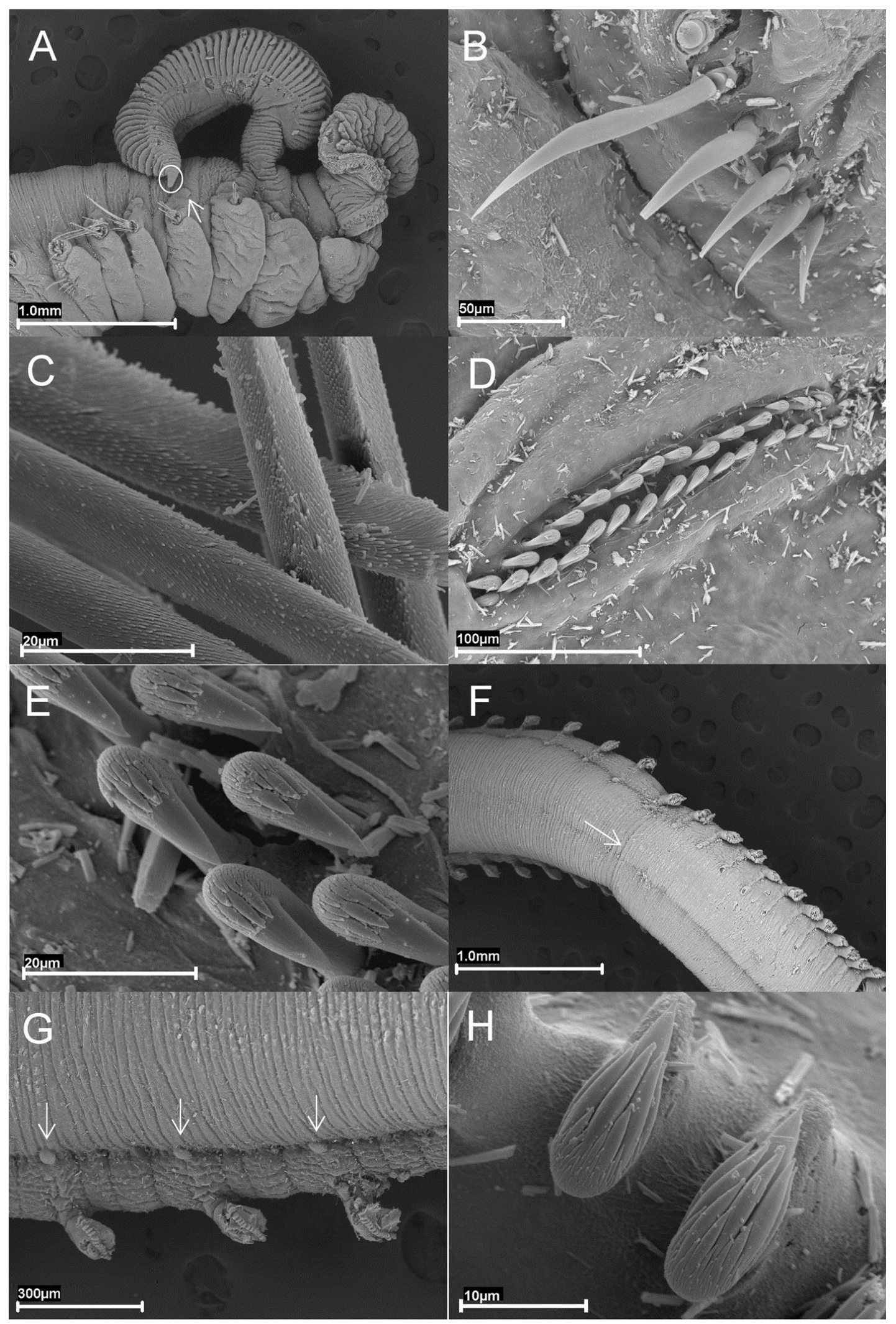

Figure 4 Terebellides longicaudatus Hessle, 1917. SEM micrographs from syntype SMNH 6636. (A) Anterior end, lateral view showing pointed projection of lobe ii (encircled) and position of dorsal papilla on chaetiger 3 (arrow); (B) Geniculate acicular hooks, 6th thoracic chaetiger; (C) Textured surface of thoracic notochaetae; (D) Thoracic unciniger, chaetiger 12; (E) Thoracic uncini, upper view; (F) Body constriction between abdominal chaetigers 17 and 18 (arrow); (G) Abdominal chaetigers 12 to 14, dorsal view showing dorsal papillae (arrow); (H) Abdominal uncini; upper view. 


\section{Type material}

Swedish Museum of Natural History, Stockholm SMNH 540 (South Georgia, mouth of Cumberland

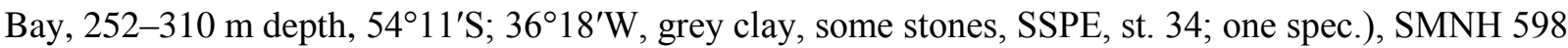
(South Georgia, Cumberland Bay, Antarctic Bay, $250 \mathrm{~m}$ depth, 54 $14^{\circ} \mathrm{S}$; $36^{\circ} 50^{\prime} \mathrm{W}$, SSPE, st. 20; one spec.), SMNH 6625 (South Georgia, Cumberland Bay, off May Bay, $75 \mathrm{~m}$ depth, 54 ${ }^{\circ} 17^{\prime} \mathrm{S} ; 36^{\circ} 28^{\circ} \mathrm{W}$, clay, algae, SSPE st. 22; three specs.), SMNH 6626 (SSPE st. 22; one spec.; HOLOTYPE), SMNH 6627 (SSPE st. 22; one spec.), SMNH 6628 (SSPE st. 22; one spec.), SMNH 6629 (South Georgia, Cumberland Bay, outside Grytviken, $95 \mathrm{~m}$ depth $54^{\circ} 22^{\prime} \mathrm{S}$; $36^{\circ} 27^{\prime} \mathrm{W}$, clay, SSPE st. 24; two specs.), SMNH 6630 (SSPE st. 34; one spec.), SMNH 6631 (SSPE st. 34; seven specs.), SMNH 6632 (SSPE st. 34; two specs.), SMNH 6633 (SSPE st. 34; one spec.), SMNH 6634 (SSPE st. 34; one spec.), SMNH 6635 (SSPE st. 34; one spec.), SMNH 6636 (SSPE st. 34; five specs.), SMNH 6637 (SSPE st. 34; one spec.), SMHN 6638 (SSPE st. 34; three specs.).

\section{Additional material}

British Museum of Natural History, London South Georgia, Antarctica. NHM 1930.10.8.2163-65 (two specs.), NHM 1930.10.8.2167-70 (three specs.), NHM 1930.10.8.2234 (one spec.), NHM 1930.10.8.2236-39 (six specs.), NHM 1930.10.8.2525 (one spec.).

United States National Museum, Washington Weddell Sea, Antarctica. USNM 47076 (USCGC Glacier, cr. 2, st. 27; $64^{\circ} 46.2^{\prime} \mathrm{S} ; 41^{\circ} 30.1^{\prime} \mathrm{W}, 4575 \mathrm{~m}$, March 19, 1969, one spec.), USNM 47075 (USCGC Glacier, cr. 2, st. $21 ; 73^{\circ} 52^{\prime} \mathrm{S} ; 31^{\circ} 18^{\prime} \mathrm{W}, 2288 \mathrm{~m}$, March 13, 1969, one spec.).

\section{Type locality}

South Georgia Island, Cumberland Bay, off May Bay, $75 \mathrm{~m}$ depth, $54^{\circ} 17^{\prime} \mathrm{S} 036^{\circ} 28^{\prime} \mathrm{W}$ (Antarctica). Clay, algae.

\section{Description (based on holotype)}

Complete specimen of $55 \mathrm{~mm}$ in length and $4 \mathrm{~mm}$ in width; body tapering posteriorly with segments increasingly shorter and compacted towards pygidium (Figure 1A). Prostomium compact; tentacular membrane surrounding the mouth and provided with one type of oral tentacles with expanded ciliated tips (Figure 1B, 2B). First segment forming an expanded structure ("lower lip") below peristomium. Eyespots absent. Branchiae arising as single structure from segments 3-4 (Figure 4A), consisting of single mid-dorsal stalked structure constituted by two pairs of similar-sized lobes; branchial lobes fused together for the most part of their length; a short additional anterior projection ("fifth lobe") also present (Figure 4A). Posterior region of superior lobes (i and ii) with pointed projection (Figure 4A). Branchial lamellae provided with ciliated rows on both sides and tufts of cilia at dorsal edge (Figure 2C-D). Lateral lappets on chaetigers 1 to 5 (segments 3 to 7), particularly developed in chaetigers 1 and 2 (Figure 1B, 2A, 3A, 4A); anterior margins separated from body wall. Rounded dorsal projections from chaetiger 1 to 5 (Figure 2A). Ventral glandular bands absent.

Notopodia numbering 18 pairs (segments 3 to 20), compact, rectangular and of similar size except those of chaetiger 1 which are smaller (Figure 3B). Neuropodia present from chaetiger 6 (segment 8 ) to pygidium. Thoracic neuropodia as broad sessile pinnules (Figures $1 \mathrm{C}, 2 \mathrm{G}$ ); abdominal neuropodia as erect pinnules (Figures 3G, 4G). Notochaetae of first chaetiger shorter and less numerous than in subsequent notopodia. All notochaetae simple, broad-winged capillaries (Figure 2E) with textured surfaces (Figure 4C) and tubular internal structure (Figure 2F). No accessory chaetae. 
First thoracic neuropodium (chaetiger 6) with 10 gently bent, acute-tipped, geniculate acicular hooks (Figures 3C, 4B) with internal structure formed by fused hollow channels (Figure 3D). Second and all subsequent thoracic neuropodia with about 45 (chaetiger 7) to about 80 (chaetiger 18) uncini; uncini of each torus arranged in several rows (Figures 2G, 4D); uncini as denticulate hooks with main fang large and surmounted by 4-6 big teeth and a crest of numerous denticles (Figures $2 \mathrm{H}, 4 \mathrm{E}$ ); dental formula: MF:4-6:œ. Abdominal neuropodia numbering 54; about 80 avicular uncini per torus with 5-6 teeth above main fang surmounted by 2-4 teeth and an upper crest of a variable number of smaller teeth (Figures 3H, 4H); dental formula: MF:5-6:2-4: $\infty$. No abdominal notopodia. One abdominal constriction between chaetigers 17 and 18 (Figures 1A, 4F).

One large nephridial papilla attached to notopodium of chaetiger 1 (segment 3), with appearance of long, distally truncated cone. Two shallow and wider buttonhole-like nephridial pores located on basal part of notopodia of chaetigers 4 and 5 (segments 6 and 7) (Figure 2A). Small papillae arising dorsally to all thoracic (Figures 3E-F) and abdominal (Figures 3G, 4G) chaetigers. Pygidium blunt, with funnellike depression with crenulated edge.

\section{Additional observations from type (SMNH) and non-type material (NHM)}

The presence of short papillar projections on the outer side of the branchial lamellae reported by SolisWeiss et al. (1991) in some Atlantic South American species and by Jouin-Toulmond and Hourdez (2006) in North Atlantic T. stroemii were not observed in this species. The damaged margin of one branchial lamella in SMNH 6625 (Figure 2D) shows the internal structure of the marginal efferent blood vessel reported by Jouin-Toulmond and Hourdez (2006) for T. stroemii. Geniculate acicular hooks are clearly acute tipped and gently bent (Figures 3C, 4B). The rows of thoracic uncini vary between 1-2 in smaller animals (Figure 4D) to 4-5 in larger ones (Figure 2G). The uncinal patch shows the highest number of uncinal rows in the central area, showing fewer rows in the formative (dorsal) and degenerative (ventral) edges. Number of abdominal chaetigers varies between 42 in smaller specimens (about $1.6 \mathrm{~cm}$ length, SMNH 6634) and 54 in larger ones (7.6 cm, NHM 1930.10.8.2234). The abdominal constriction between abdominal chaetigers 17 and 18 was observed in all specimens; this character was not reported in any other species of Terebellides. As Monro (1930Monro, C. C. A. 1930. Polychaete worms.. Discovery Reports, 2:1-222.:199) pointed out, one specimen has 19 notopodia (NHM 1930.10.8.2234), the neuropodia being a very small patch; this extra thoracic chaetiger is only present on the right side, the left having the usual abdominal nature.

The two trichobranchid specimens identified as T. longicaudatus by Hartman (1978) (USNHM 4707576) do not correspond to this species. Although these specimens are in poor condition and have lost the branchiae, they have large notochaetae in the first chaetiger and a small number of uncini in thoracic neuropodia which suggests that they cannot represent specimens of T. longicaudatus.

\section{Ecological notes}

Type material was collected in shallow muddy bottoms with stones at depths of between 75 and $310 \mathrm{~m}$. Monro (1930) reported this species in similar sediments from 110-500 m.

\section{Reported distribution}

South Georgia (Hessle 1917; Monro 1930). The only specimen reported by Monro (1930) out of South Georgia, from station 182 in the Schollaert Channel (Palmer Archipelago) (NHM 1930.10.8.2166), corresponds to T. kerguelensis. 
Hessle 1917:140, plate I, figure 18, Textfigure 31; Hartman 1953, page 11.

\section{Type material}

Swedish Museum of Natural History, StockholmSMNH 6639 (Antarctic, Graham region, $360 \mathrm{~m}$ depth, $64^{\circ} 03^{\prime} \mathrm{S} ; 56^{\circ} 37^{\prime} \mathrm{W}$, soft clay, SSPE st. 8; two specs.), SMNH 6640 (SSPE, st. 8; two specs.), SMNH 6641 (Antarctic, Graham region, Admiralitäts Sund, 5-9 m depth, $64^{\circ} 20^{\prime} \mathrm{S} ; 57^{\circ} \mathrm{W}$, small stones and gravel, SSPE, st. 09; one spec.), SMNH 541 (SSPE, st. 8; one spec.).

\section{Reported distribution}

Graham's Land, Antarctic Peninsula (Hessle, 1917Hessle, C. 1917. Zur Kenntnis der terebellomorphen Polychaeten.. Zoologiska bidrag frän Uppsala, 5: 39-258.; Hartman, 1953Hartman, O. 1953. Nonpelagic polychaeta of the Swedish Antarctic expedition 1901-1903.. Further Zoological Results of the Swedish Antarctic Expedition 1901-1903, 4: 1-83.).

\section{Remarks}

Hessle (1917:139) characterizes this species by the absence of lateral lappets in segments 3 and 4 (chaetigers 1 and 2) and by the small number (10-20 per unciniger) and shape (5 teeth over the rostrum and 2-3 upper teeth) of thoracic uncini. Notochaetae of chaetiger 1 are of about the same length as the rest of the thoracic notochaetae, and prostomium, branchiae and distribution and shape of chaetae is similar to those of T. stroemii, T. minutus and T. longicaudatus. Syntypes SMNH 541 and 6639 are of large size (ca. $60 \mathrm{~mm}$ ) and have 34 and 37 abdominal chaetigers, respectively; those numbers are smaller than those in specimens of $T$. longicaudatus of similar length (e.g. 54 abdominal neuropodia in holotype which is $55 \mathrm{~mm}$ in length). The SMNH 541 specimen has oocytes and chaetigers 1 to 3 have lateral lappets. The two specimens labelled as SMNH 6640 are anterior ends which represent those illustrated by Hessle to draw the uncini illustrated in the original description (cf. Hessle 1917, TextFigure 31:140 and pl. I, figure 18) because the sides of those specimens seem to have been dissected. Only one specimen has branchiae which show cilia on lamellae arranged in a similar fashion as those of T. kerguelensis (Parapar and Moreira 2008).

Terebellides minutus Hessle, 1917

Hessle 1917:138-139, plate I, figure 16, Textfigure 29; Monro 1930:198, figure 83; Hartman 1953:11.

\section{Type material}

Swedish Museum of Natural History, Stockholm: SMNH 542 (TYPE, South Georgia, Cumberland Bay, the inlet of Westfjord, $250 \mathrm{~m}$ depth, $54^{\circ} 15^{\prime} \mathrm{S}, 36^{\circ} 25^{\prime} \mathrm{W}$, loose clay, SSPE 1901-03, st. 18; one spec.), SMNH 6642 (SSPE st. 18; 1 spec.), SMNH 6643 (SSPE, st. 18; three specs.), SMNH 6644 (South Georgia, Cumberland Bay, $250 \mathrm{~m}$ depth, $54^{\circ} 12^{\prime} \mathrm{S}, 36^{\circ} 50^{\prime} \mathrm{W}$, clay, algae; SSPE st. 20; five specs.), SMNH 6645 (SSPE st. 20; one spec.), SMNH 6646 (SSPE st. 20; three specs.), SMNH 6647 (SSPE st. 20; five specs.), SMNH 6648 (South Georgia, off May Bay, $75 \mathrm{~m}$ depth, $54^{\circ} 17^{\prime} \mathrm{S}, 36^{\circ} 28^{\prime} \mathrm{W}$, clay, algae; SSPE st. 22; 13 specs.), SMNH 6649 (SSPE st. 22; two specs.), SMNH 6650 (SSPE st. 22; two specs.), SMNH 6651 (South Georgia, outside the mouth of Moränenfjord, 64-74 m depth, 54 $23^{\prime} \mathrm{S} ; 36^{\circ} 26^{\prime} \mathrm{W}$, grey clay with gravel and stones; SSPE st. 23; 17 specs.), SMNH 6652 (South Georgia, Cumberland 
Bay, outside Grytviken, $95 \mathrm{~m}$ depth, $54^{\circ} 22^{\prime} \mathrm{S}, 36^{\circ} 27^{\prime} \mathrm{W}$, clay; SSPE st. 24; 33 specs.), SMNH 6653 (SSPE st. 24; one spec.), SMNH 6654 (SSPE st. 24; seven specs.), SMNH 6655 (SSPE st. 24; one spec.), SMHN 6656 (SSPE st. 24; three specs.).

\section{Reported distribution}

Patagonia (Hessle 1917; Hartman 1953) and South Georgia, Antarctica (Monro 1930).

\section{Remarks}

Hessle (1917Hessle, C. 1917. Zur Kenntnis der terebellomorphen Polychaeten.. Zoologiska bidrag frän Uppsala, 5: 39-258.:138) distinguishes T. minutus from T. kerguelensis only on the basis of the shape of the thoracic and abdominal uncini. These differences are, however, not clearly explained in the original description and accompanying drawings. Here, examination of a large number of specimens preserved in good condition from SMNH showed that distinction of the two species based on shape of uncini cannot be maintained thus confirming that $T$. minutus and $T$. kerguelensis are the same species. Syntypes measured between 0.9 and $3.5 \mathrm{~cm}$ in length and numbers of thoracic and abdominal uncini have little variation among individuals. On the other hand, the number of thoracic chaetigers ranges from 13 to 15 in large individuals and between 9 and 10 in smaller ones whereas the number of abdominal chaetigers is 33-35 and 28-29, respectively. In addition, dorsal and ventral branchial lobes have a pointed papillar projection located on the posterior face.

\section{Discussion}

New examination of type material of Terebellides longicaudatus has confirmed that this is a valid species clearly distinguishable from Terebellides kerguelensis McIntosh, 1885, the most wide spread species of the genus in Antarctic waters and recently redescribed by Parapar and Moreira (2008). Thus, $T$. longicaudatus is characterized by the presence of wide lateral lappets in segments 3 and 4 (chaetigers 1 and 2), first thoracic notopodium which is greatly reduced and large thoracic uncinigerous tori provided with many (45 to 80 ) uncini and numerous abdominal chaetigers. Those numbers of uncini and abdominal chaetigers are the highest ever registered in any other species of the genus.

Hessle (1917) differentiated $T$. longicaudatus and $T$. kerguelensis from $T$. minutus and $T$. antarcticus solely according to the shape of thoracic and abdominal uncini, and highlighting the angle formed between the rostrum and the main axis in long thoracic uncini as well as to the number of secondary teeth surmounting the rostrum in short abdominal uncini. These characters were, however, not considered as taxonomically relevant in subsequent studies. Here, examination of type series by means of Scanning Electron Microscope showed that the differences stated by Hessle (1917) are just within the range of variability of $T$. kerguelensisand thus $T$. minutus, $T$. antarcticus and $T$. kerguelensis can be considered to be the same species. Thus, it should be pointed out again that characters based on fine setal structure such as those mentioned above should be used with caution in polychaete taxonomy (Hausen 2005:40). For example, Ohwada and Nishino (1991) found that the number of apical teeth in hooded hooks of the spionid Prionospio japonica can vary significantly within the same specimen.

In addition, SEM examination showed that setal internal organization is relatively homogenous with presence of many longitudinal hollow channels. Similar observations were made by Bartholomaeus (1995) in Pectinaria and Spirorbis, Meyer and Bartholomaeus (1996) in Owenia and Hausen (2005) in Nicolea and Pectinaria. 
The papillae observed dorsally on all thoracic and abdominal chaetigers of $T$. longicaudatus were previously reported for $T$. stroemi (as "abdominal notopodial rudiments") by Williams (1984: p. 127) and for T. kerguelensis by Parapar and Moreira (in press) as "thoracic papillae". These papillae could be related to some sensory structures. Rouse (2000), and later Rouse and Pleijel (2001:27) and Purschke (2005:63) describe the "lateral organs" which are ciliated pits or papillae present between noto- and neuropodia (or dorsal to the neuropodia when notopodia are absent). Those authors pointed out that these structures were found in a number of polychaete families such as the Pectinariidae. A homology of those structures with the "dorsal cirrus organ" described by Hayashi and Yamane $(1994,1997)$ in some Eunicida and Phyllodocida has been suggested by Purschke (2005).

On the other hand, Garraffoni and Lana (2003:359), in their revision of the Brazilian species of Terebellides, provide a key to all known species of the genus but they leave out $T$. longicaudatus because they consider that this species was not well characterized. According to this key, T. narribri Hutchings and Peart, 2000 is the closest species to T. longicaudatus, but the latter can be distinguished by the presence of large lateral lobes in chaetigers 1 to 5 , first notopodium poorly developed when compared to the following ones, the first thoracic acicular neurochaetae are gently bent and thoracic neuropodial fascicles are wider and provided with numerous uncini.

The presence of lateral lappets in anterior thoracic segments (particularly developed in segment 3 and 4) and the smaller number and length of first thoracic notochaetae in T. longicaudatus are characters shared with other Terebellides species. According to Hutchings and Peart (2000, table 3A) the only species with both characters are: T. japonica Moore, 1903, T. lanai Solis-Weiss et al. 1991 and T. woolawa Hutchings and Peart, 2000. Terebellides japonica, originally described as $T$. stroemii var. japonica by Moore (1903), was synonymized with T. stroemii by Imajima and Hartman (1964) and later regarded as valid species by Imajima and Williams (1985:10) and Hutchings and Peart (2000:249). This species has fewer thoracic neurochaetae (about 40 per torus) than $T$. longicaudatus and the acicular chaetae of sixth thoracic chaetiger have a pointed sheath covering a bluntly rounded core. The tropical species Terebellides lanai Solis-Weiss et al., 1991SolisWeiss, V., Fauchald, K. and Blankensteyn, A. 1991. Trichobranchidae (Polychaeta) from shallow warm water areas in the western Atlantic Ocean.. Proceedings of the Biological Society of Washington, 104: 147-158. differs from T. longicaudatus in having a smaller number of abdominal chaetigers (2529) whereas the Australian species $T$. woolawa only has one pair of nephridial papillae on segment 3 and lacks buttonhole-like papillae in chaetigers 4 and 5 .

The presence of a body constriction between abdominal chaetigers 17-18 was not recorded before in any known species of Terebellides. Therefore, this character may be regarded as of taxonomic value to distinguish T. longicaudatus in the same way as is the dorsal hump present in T. anguicomus Müller, 1858, T. carmenensis Solís-Weiss et al., 1991 and T. totae Bremec and Elias, 1999.

Finally, as a result of this study, the traditional consideration of Terebellides antarcticus and Terebellides minutus as junior synonyms of Terebellides kerguelensis is supported. Thus, the study of the syntypes loaned by the Swedish Museum of Natural History revealed no differences with the type material of $T$. kerguelensisfrom Kerguelen Island studied by Parapar and Moreira (2008).

\section{Acknowledgements}

The authors wish to thank Elin Sigvaldadottir and Karin Sindemark (SMNH), Emma Sherlock (BMNH) and William Moser (USNM) for the loan of Hessle's, McIntosh's and Monro's, and Hartman's 
specimens, respectively. Many thanks are also given to R. Barreiro (RIAIDT, Universidade de Santiago de Compostela, Spain) and A. Castro (SAIN, Universidade da Coruña) who assisted with the preparation of specimens and use of the SEM, D. Romero (Universidade da Coruña) for the line drawings and J. García-Carracedo for the translation of Hessle's descriptions. Special thanks to one anonymous referee whose comments greatly contributed to improving this paper. This work was partially supported by MCYT Antarctic Program CGL2004-01856.

\section{References}

Arwidsson I. 1911. Die Maldaniden. Wissenschaftliche Ergebnisse der Schwedischen Südpolar Expedition 1901-1903. 6:1-44.

Augener H. 1932. Antarktische und Antiboreale Polychaeten nebst einer Hirundinee. Scientific Results of the Norwegian Antarctic expedition, 1927-28. Norske Videnskaps Akademy Oslo. 9:1-86.

Bartholomaeus T. 1995. Structure and formation of the uncini in Pectinaria koreni, Pectinaria auricoma (Terebellida) and Spirorbis spirorbis (Sabellida): implications for annelid phylogeny and the position of the Pogonophora. Zoomorphology. 115:161-177.

Bergström E. 1914. Zur Systematik des Polychaeten Familie der Phyllodociden. Zoologiska bidrag frän Uppsala. 3:37-224.

Bergström E. 1916. Die Polynoiden des schwedischen Südpolar-Expedition 1901-1903. Zoologiska bidrag frän Uppsala. 4:249-304.

Bremec CS, Elias R. 1999. Species of Terebellides from South Atlantic waters off Argentina and Brazil (Polychaeta: Trichobranchidae). Ophelia. 51:177-186.

Cantone G, Sanfilippo R. 1992. Polychaeta from Terra Nova Bay (Ross Sea, Antarctica). In: Gallardo VA, Ferretti O, Moyano HI, editors. Oceanografía in Antartide. Rome (Italy): ENEA Progetto Antartide. p. 371-381.

Díaz-Díaz O, Liñero-Arana I. 2003. New records of Trichobranchidae (Annelida: Polychaeta) from Venezuela. Boletín del Centro de Investigaciones Biológicas. 37:182-190.

Ehlers E. 1913. Die Polychaeten-Sammlungen der Deutschen Südpolar-Expedition 1901-1903. Deutsche Südpolar Expedition. 13:397-598.

Garraffoni ARS, Lana PC. 2003. Species of Terebellides (Polychaeta, Terebellidae, Trichobranchidae) from the Brazilian coast. Iheringia, Série Zoologia. 93:355-363.

Garraffoni ARS, Lana PC. 2004. Cladistic analysis of the subfamily Trichobranchinae (Polychaeta: Terebellidae). Journal of the Marine Biological Association of the United Kingdom. 84:973-982.

Garraffoni ARS, Lana PC, Hutchings P. 2005. A catalogue of the Trichobranchidae (Polychaeta: Terebellidae) of the world. Zootaxa. 1065:1-27.

Hartman O. 1953. Non-pelagic polychaeta of the Swedish Antarctic expedition 1901-1903. Further Zoological Results of the Swedish Antarctic Expedition 1901-1903. 4:1-83.

Hartman O. 1959. Catalogue of the Polychaetous Annelids of the world. Parts 1 and 2. Occasional Papers of the Allan Hancock Foundation Publications. 23:1-628.

Hartman O. 1966. Polychaeta Myzostomidae and Sedentaria of Antarctica. Antarctic Research Series. $7: 1-158$.

Hartman O. 1967. Polychaetous Annelids collected by the USNS Eltanin and Staten Island cruises chiefly from Antarctic seas. Allan Hancock Monographs on Marine Biology. 2:1-387.

Hartman O. 1978. Biology of Antarctic Seas, 6. Polychaeta from the Weddell Sea quadrant, Antarctica. Antarctic Research Series. 26:125-223.

Hartmann-Schröder G, Rosenfeldt P. 1989. Die Polychaeten der "Polarstern'”-Reise ANT III/ 2 in die Antarktis 1984. Teil 2: Cirratulidae bis Serpulidae. Mitteilungen aus dem Hamburgischen Zoologischen Museum und Institut. 86:65-106. 
Hartmann-Schröder G, Rosenfeldt P. 1991. Die Polychaeten der "Walther Herwig"-Reise 68/ 1 nach Elephant Island (Antarktis) 1985. Teil 2: Acrocirridae bis Sabellidae. Mitteilungen aus dem Hamburgischen Zoologischen Museum und Institut. 88:73-96.

Hausen H. 2005. Chaetae and chaetogenesis in polychaetes (Annelida). Hydrobiologia. 535/ 536:37-52.

Hayashi I, Yamane S. 1994. On a probable sense organ newly found in some eunicid polychaetes. Journal of the Marine Biological Association of the United Kingdom. 74:765-770.

Hayashi I, Yamane S. 1997. Further observations of a recently found sense organ in some euniceforms, with special reference to Lumbrinereis longifolia (Polychaeta, Lumbrinereidae). Bulletin of Marine Science. 6:564-574.

Hessle C. 1917. Zur Kenntnis der terebellomorphen Polychaeten. Zoologiska bidrag frän Uppsala. 5:39-258.

Hessle C. 1925. Einiges über die Hesioniden und die Stellung der Gattung Ancistrosyllis. Arkiv für Zoologi Stockholm. 17:1-37.

Holthe T. 1986. Evolution, systematics, and distribution of the Polychaeta Terebellomorpha, with a catalogue of the taxa and a bibliography. Gunneria. 55:1-236.

Hutchings P, Peart R. 2000. A revision of the Australian Trichobranchidae (Polychaeta). Invertebrate Taxonomy. 14:225-272.

Imajima M, Hartman O. 1964. The polychaetous annelids of Japan. Part II. Occasional Papers of the Allan Hancock Foundation Publications. 26:1-452.

Imajima M, Williams SJ. 1985. Trichobranchidae (Polychaeta) chiefly from the Sagami and Suruga Bays, collected by R/V Tansei-Maru (Cruises KT-65-76). Bulletin of the National Science Museum. 11:7-18.

Johansson KE. 1922. On some new tubicolous annelids from Japan, the Bonin Islands and the Antarctic. Arkiv für Zoologi Stockholm. 15:1-11.

Johansson KE. 1927. Beiträge zur Kenntnis der Polychaeten-Familien Hermellidae, Sabellidae und Serpullidae. Zoologiska bidrag frän Uppsala. 11:1-184.

Jouin-Toulmond C, Hourdez S. 2006. Morphology, ultrastructure and functional anatomy of the branchial organ of Terebellides stroemii (Polychaeta: Trichobranchidae) and remarks on the systematic position of the genus Terebellides. Cahiers de Biologie Marine. 47:287-299.

Kritzler H. 1984. Family Trichobranchidae Malmgren, 1865. In: Uebelacker JM, Johnson PG, editors. Taxonomic guide to the Polychaetes of the northern Gulf of Mexico. Volume 7. Metairie (LA): U.S. Department of Interior, Minerals and Management Service. 53.1-53.6.

Levenstein RY. 1964. Polychaetous annelids of the families Terebellidae and Trichobranchidae from the Antarctic and sub Antarctic. Biological reports of the Soviet Antarctic Expedition (1955-1958). Vol. 2. Studies of Marine Fauna II(X):173-189. Washington, D.C.: National Science Foundation [Translated from Russian original of 1964].

Meyer R, Bartholomaeus T. 1996. Ultrastructure and formation of the hooked chaetae in Owenia fusiformis delle Chiaje, 1842: implications for annelid phylogeny. Canadian Journal of Zoology. 74:2143-2153.

Monro CCA. 1930. Polychaete worms. Discovery Reports. 2:1-222.

Monro CCA. 1936. Polychaete worms, II. Discovery Reports. 12:59-198.

Monro CCA. 1939. Polychaeta. B.A.N.Z. Antarctic Research Expeditions, 1929-31. Reports - Series B (Zoology and Botany). 4:89-156.

Moore JP. 1903. Polychaeta from the coastal slope of Japan and from Kamchatka and Bering Sea. Proceedings of the Academy of Natural Science. 55:401-490.

Nilsson D. 1912. Beitra“ge zur Kenntnis des Nervensystems der Polychaeten. Zoologiska bidrag frän Uppsala. 1:85-161.

Ohwada T, Nishino Y. 1991. Morphological variations hooded hooks in Prionospio japonica (Polychaeta, Spionidae). Bulletin of Marine Science. 48:246-250. 
Parapar J, Moreira J. 2008. Redescription of Terebellides kerguelensis stat. nov. McIntosh, 1885 (Polychaeta: Trichobranchidae) from Antarctic and subantarctic waters. Helgoland Marine Research. 62:143-152.

Parapar J, San Martin G. 1997. "Sedentary" polychaetes of the Livingston Island shelf (South Shetlands, Antarctica), with the description of a new species. Polar Biology. 17:502-514.

Purschke G. 2005. Sense organs in polychaetes (Annelida). Hydrobiologia. 535/536:53-78.

Rouse GW. 2000. Morphology and Physiology. In: Beesley PL, Ross GJB, Glasby CJ, editors. Polychaetes and allies: the southern synthesis. Fauna of Australia. Vol. 4A Polychaeta, Myzostomida, Pogonophora, Echiura, Sipuncula. Melbourne (Australia): CSIRO Publishing. p. 932.

Rouse GW, Pleijel F. 2001. Polychaete Anatomy. In: Rouse GW, Pleijel F, editors. Chapter 3, Polychaetes. Oxford (UK): Oxford University Press. p. 18-38.

Rozbaczylo N, Moreno R, D1'az-Díaz O, Martı'nez S. 2006. Poliquetos bentónicos submareales de fondos blandos de la región de Aysén, Chile: Clado Terebellida (Annelida, Polychaeta). Ciencia y Tecnología Marinas. 29:71-90.

San Martin S, Parapar J, Gárcia FJ, Redondo MS. 2000. Quantitative analysis of soft bottoms infaunal macrobenthic polychaetes from South Shetland Islands (Antartica). Bulletin of Marine Science. 67:83-102.

Sicinski J. 2004. Polychaetes of Antarctic sublittoral in the proglacial zone (King George Island, South Shetland Islands). Polish Polar Research. 25:67-96.

Sicinsky J, Janowska E. 1993. Polychaetes of the shallow sublittoral of Admiralty Bay, King George Island, South Shetland Islands. Antarctic Science. 5:161-167.

Solis-Weiss V, Fauchald K, Blankensteyn A. 1991. Trichobranchidae (Polychaeta) from shallow warm water areas in the western Atlantic Ocean. Proceedings of the Biological Society of Washington. 104:147-158.

Söderström A. 1920. Studien über die Polychaetenfamilien Spionidae [Lic. Phil. dissertation]. [Uppsala University]. p. 1-286.

Støp-Bowitz C. 1951. Polyche 'tes pe'lagiques de l'expédition suédoise Antarctique 1901-1903. Further Zoological Results of the Swedish Antarctic Expedition 1901-1903. 4:1-14.

Williams SJ. 1984. The status of Terebellides stroemi (Polychaeta: Trichobranchidae) as a cosmopolitan species, based on a worldwide morphological survey, including description of a new species. In: Hutchings PA, editor. Proceedings of the first international Polychaete conference. Sydney, Australia: The Linnean Society of New South Wales. p. 118-142. 